\title{
Artículos
}

\section{Las ideologías políticas en América Latina en el siglo XX}

\author{
Luis Armando González
}

\section{Resumen}

El autor examina las principales ideologías presentes en el debate político latinoamericano durante el siglo XX. Dedica particular atención a la ideología socialista-comunista, que es considerada como la de mayor importancia por su coherencia y simpleza teóricas, su eficacia política y la pasión sin límites que despierta en sus militantes. Su tesis es que, al cierre del siglo XX, el nacionalismo, el antiimperialismo, el nacionalismo revolucionario y el socialismocomunismo se han quebrado como proyectos de transformación social, lo cual ha traído consigo una situación de incertidumbre política e ideológica que caracteriza al momento actual.

"Los dos regímenes [el nazismo y el comunismo estalinista] dan a conocer casi al mismo tiempo dos rasgos que los apartarán de la humanidad civilizada: el reinado del partido único sobre el Estado, y la dominación no compartida de dicho partido por un sólo hombre. Sistemas políticos sin leyes fijas, en los que nada protege a nadie y la policía política puede detener y hacer desaparecer absolutamente a cualquiera, salvo a uno solo".

Furet, El pasado de una ilusión, 1995. 
"En cualquier caso, una parte de nuestra búsqueda de un mundo mejor debe consistir en la búsqueda de un mundo en el que no se fuerza a otros a sacrificar su vida en razón de una idea".

K. Popper, En busca de un mundo mejor, 1994.

\section{Introducción}

El siglo XX ha visto nacer en América Latina las más diversas interpretaciones de la realidad social, económica y política. Los distintos países y sociedades han dado cobijo a las ideas más dispares sobre lo que constituye su razón de ser, sus orígenes, su situación actual y su futuro. Nacionalismo, nacionalismo revolucionario, desarrollismo, socialismo y comunismo han sido referentes permanentes de acción sociopolítica; quienes los han abanderado no han sido sólo las élites intelectuales, sino amplios grupos sociales que se han movilizado, organizado y sacrificado en pro de la realización de los ideales prometidos.

No cabe duda de que en el siglo XX en América Latina, al igual que en Europa, miles de personas han sido sacrificadas ante el altar de las ideologías. Miles de vidas vieron truncadas sus aspiraciones de una situación personal y social más digna y humana, y otras muchas sacrificaron dimensiones esenciales de su vida personal para responder a las exigencias de la disciplina ideológica. Nacionalismo, nacionalismo revolucionario, desarrollismo, socialismo y comunismo son las matrices ideológicas que han orientado el quehacer sociopolítico de los hombres y las mujeres latinoamericanos en el siglo XX. Sin entender esas matrices ideológicas, difícilmente se entenderá el rumbo seguido por los países latinoamericanos a lo largo del siglo que está por finalizar, así como tampoco se entenderá la incertidumbre sociopolítica que caracteriza al momento histórico actual.

Cada una de las matrices ideológicas apuntadas, en su momento, fue operante y orientó la praxis sociopolítica de importantes grupos sociales. También en su momento entró en crisis y puso al descubierto sus debilidades más sustantivas. En la actualidad, estamos ante la crisis de la más importante ideología política del siglo XX: la comunista, la cual - ya fuese por aceptación o rechazo- dio lugar a las reacciones y a los compromisos políticos más radicales. La crisis de la ideología comunista, además, no ha supuesto, como en el pasado, la emergencia de una matriz ideológica alternativa, pues ella no sólo pretendió asumir lo mejor de las matrices anteriores, sino que se erigió como la última y definitiva propuesta de emancipación social, política y económica.

El propósito de estas notas es el examen de la naturaleza de las matrices ideológicas señaladas, especialmente de la comunista. En cierto modo, el análisis de los derroteros del comunismo en América Latina es el tema central de este trabajo. Para entender el sentido de las ideologías políticas en América Latina se seguirán dos vías que serán complementarias: en la primera, se examinarán algunas de las personalidades intelectuales y políticas más importantes que con su vida y obra contribuyeron decisivamente a la configuración de las ideologías políticas que han marcado la realidad latinoamericana en el siglo XX. En la segunda, el punto central será específicamente la idea comunista, en la que se enfatizará tanto su dimensión intelectual-racional como su dimensión pasional, en virtud de la cual la vida personal de quienes la asumieron se tradujo en renuncias radicales. Este último aspecto es sumamente interesante, puesto que sin entenderlo es imposible entender también el apasionamiento y la renuncia a valores y estilos de vida considerados "burgueses" que caracterizaron a los militantes comunistas. Más aún, sin su examen es imposible entender la sumisión incondicional y absoluta al jefe o al líder, propios de los militantes comunistas auténticos.

Ciertamente, es difícil hacer un ejercicio como el propuesto, es decir, acceder a los compromisos y renuncias efectivas-sentimentales que caracterizaron (¿y caracterizan?) a los militantes comunistas. Sin embargo, la tarea no es imposible, sobre todo si se presta atención a quienes suelen dejar testimonio escrito de sus ideas y sentimientos: los intelectuales. En el siglo $\mathrm{XX}$, muchos de los 
intelectuales europeos más importaptes tuvieron algo que ver con el comunismo. $\mathrm{Y}$, entre estos; quienes más apasionadamente se vincularon con el comunismo, lo despreciaron y lo amaron, fueron los artistas (literatos y pintores).

Esta temática, con todo y lo atractiva que resulta, excede las pretensiones de estas notas, cuyo interés expreso es América Latina. Aquí es posible rastrear las pasiones comunistas, y nosotros lo haremos siguiéndole la pista a una intelectual italiana que vivió en México en los años veinte y que ejemplifica con meridiana claridad los afectos, compromisos y renuncias que forzosamente tenía que hacer alguien que se adscribiera en serio al comunismo. El nombre de esa intelectual, fotógrafa de profesión, es Tina Modotti. En su momento habrá que detenerse en el caso de la Modotti; por

Nacionalismo revolucionario,
desarrollismo, socialismo y comunismo
son las matrices ideológicas que han
orientado el quehacer sociopolítico
de los hombres y las mujeres
latinoamericanos en el siglo XX.
ahora, baste decir que para rastrear la vida de esta fotógrafa italiana se ha utilizado el libro Tínisima de la mexicana Elena Poniatowska.

Así pues, el trabajo tendrá como apartados centrales los dos bloques temáticos apuntados: primero: un examen más conceptual y sistemático de las ideologías políticas latinoamericanas; $y$, segundo, una aproximación a la dimensión pasional del comunismo, que ha sido sin duda - justamente por el carácter y alcance de las pasiones que fue (iy es?) capaz de suscitar - la ideología política más importante en el siglo XX a nivel latinoamericano. Como corolario, se hará una reflexión sobre las incertidumbres ideológicas que acechan a América Latina a finales del segundo milenio, una vez que las certezas ideológicas que lo han dominado desde principios de siglo han dejado de ser tales.

2. Consideraciones preliminares: filiaciones ideol6gicas del discurso político latinoamericano ${ }^{1}$

Entre las filiciaciones ideológicas más relevantes del discurso político latinoamericano ocupan un lugar destacado las siguientes: nación, nacionalismo, antiimperialismo, desarrollismo, colonialismo interno, nacionalismo revolucionario, socialismo y comunismo. Todas esas nociones tienen en común no sólo el haber sido parte de elaboraciones intelectuales más o menos sistemáticas, sino el haber servido de instrumentos de movilización política. Así, América Latina gozó de la presencia de intelectuales de renombre que no sólo hacían grandes esfuerzos para articular los conceptos aludidos, a modo de formar una cosmovisión coherente de la realidad social latinoamericana y de las condiciones para su transformación, sino que, al mismo tiempo, muchos se hacian protagonistas de una práctica política tendiente a hacerlos realidad.

Del conjunto de nociones apuntadas, cuatro son las básicas: nacionalismo, antiimperialismo, nacionalismo, revolucionario y socialismo-comunismo.

(a) La primera nace en el marco de las luchas independentistas con el subsiguiente proceso de formación de los estados nacionales a que las mismas dan lugar. Se destaca en ella el problema de la identidad nacional, la integración de los actores sociales diversos que conforman la sociedad y la alianza multiclasista (pacto social) en tomo a las clases medias. Es una filiación ideológica que pierde su fuerza a principios del siglo XX, en buena medida por las transformaciones mundiales $y$ regionales que la penetración del capital extranjero y la expansión de los países centrales traen consigo.

(b) La segunda comienza a ganar fuerza hacia los años veinte, cuando las discusiones sobre el imperialismo han cobrado fuerza en los círculos de la izquierda - motivados en buena medida por el libro de V. Lenin, El imperialismo, fase superior del capitalismo. Su punto fuerte es la defensa del patrimonio nacional

1. Esta parte del ensayo, así como el apartado 3, se apoya en las ideas de Francisco Zapata. Ver Ideología y política en América Latina, México, 1990. 
(recursos naturales), a lo que se suma la defensa del patrimonio cultural y del pasado prehispánico.

(c) El nacionalismo y el antiimperialismo confluyen, hacia los años treinta, en el nacionalismo revolucionario, que encuentra, primero, en la revolución méxicana ${ }^{2} y$, después, en los regímenes populistas - como el peronista y el aprista- a sus mayores portavoces ${ }^{3}$. Sus rasgos básicos son: recuperación de los recursos naturales para la nación, educación y cultura para todos, integración cultural, inversión pública, anitiimperialismo, rechazo a la oligarquía y fomento a la organización y movilizaciones sociales. Todo ello inserto en un proyecto de unidad nacional en tomo a un Estado gestionado por las clases medias.

(d) La cuarta llega a América Latina con los inmigrantes italianos y españoles, aunque tiene un sustrato de clase importante la formación de los sindicatos urbanos y los sindicatos mineros. Ambos - socialismo y comunismo-no adquieren en un principio la distinción que, por el contrario los caracteriza y enfrenta en Europa, donde son tajantes las líneas divisorias existentes entre la socialdemocracia y el marxismo-leninismo en ciemes. Los rasgos que predominan en el comunismo-socialismo latinoamericano tienen, en la época que nos ocupa, un fuerte predominio del marxismo-leninismo, con notables elementos anarquistas y anarcosindicalistas. De ese modo, para esta filiación ideológica, la dinámica social se explica por la lucha de clases, la oposición de la clase obrera al desarrollo capitalista y la penetración imperialista que hace que la lucha contra el capitalismo sea una lucha contra el imperialismo.
El comunismo-socialismo latinoamericano, pues, abandona la idea de que la unidad nacional es el principio actuante de la política, ya que el mismo radica en las clases sociales y su lucha. Además, la sociedad termina por ser contemplada como una estructura heterogénea con grupos subordinados a los intereses de unas élites económicamente dominantes. Como no podía ser para menos, entre los grupos subordinados está la pọblación indígena, que comparte con los demás grupos explotados dicha condición. Sin embargo, dentro de todos estos grupos subordinados, el proletariado - léase la clase obrera- es el más importante a la hora de hacer avanzar la lucha anticapitalista $y$ antiimperialista.

Es importante hacer notar que, desde muy temprano, la filiación socialista-comunista trata de aplicar a América Latina las ideas de modo de producción precapitalista y capitalista, entendiendo al primero como feudal, colonial e indígena, $y$ al segundo como dependiente del imperialismo. Ello introduce una novedad respecto a la ortodoxia que comienza a propagarse desde la Rusia bolchevique desde donde suele hablarse de un capitalismo y un proletariado a secas. Igualmente novedosa resulta la idea de un actor indígena, cuando la ortodoxia insiste en que sólo hay una clase revolucionaria - la clase obreraque es la única depositaria de la transformación social.

En parte, es por estos elementos "novedosos" que el socialismo-comunismo latinoamericano tiene dificultades para ser aceptado por el movimiento comunista internacional, en cuyo seno la determinación de quién es un verdadero comunista y quién no lo es depende cada vez más de los dirigentes rusos. Habrá que esperar hasta los años treinta, cuando comienzan a establecerse los partidos comunistas, para que el socialismo-comunismo latinoamericano logre institucionalizarse.

2. Ver M. M. Bomemann (Ed.), El agrarismo de la revolución mexicane, Madrid, 1990.

3. Ver A. Iturrieta (Ed.), El pensamiento peronista, Madrid, 1990. 


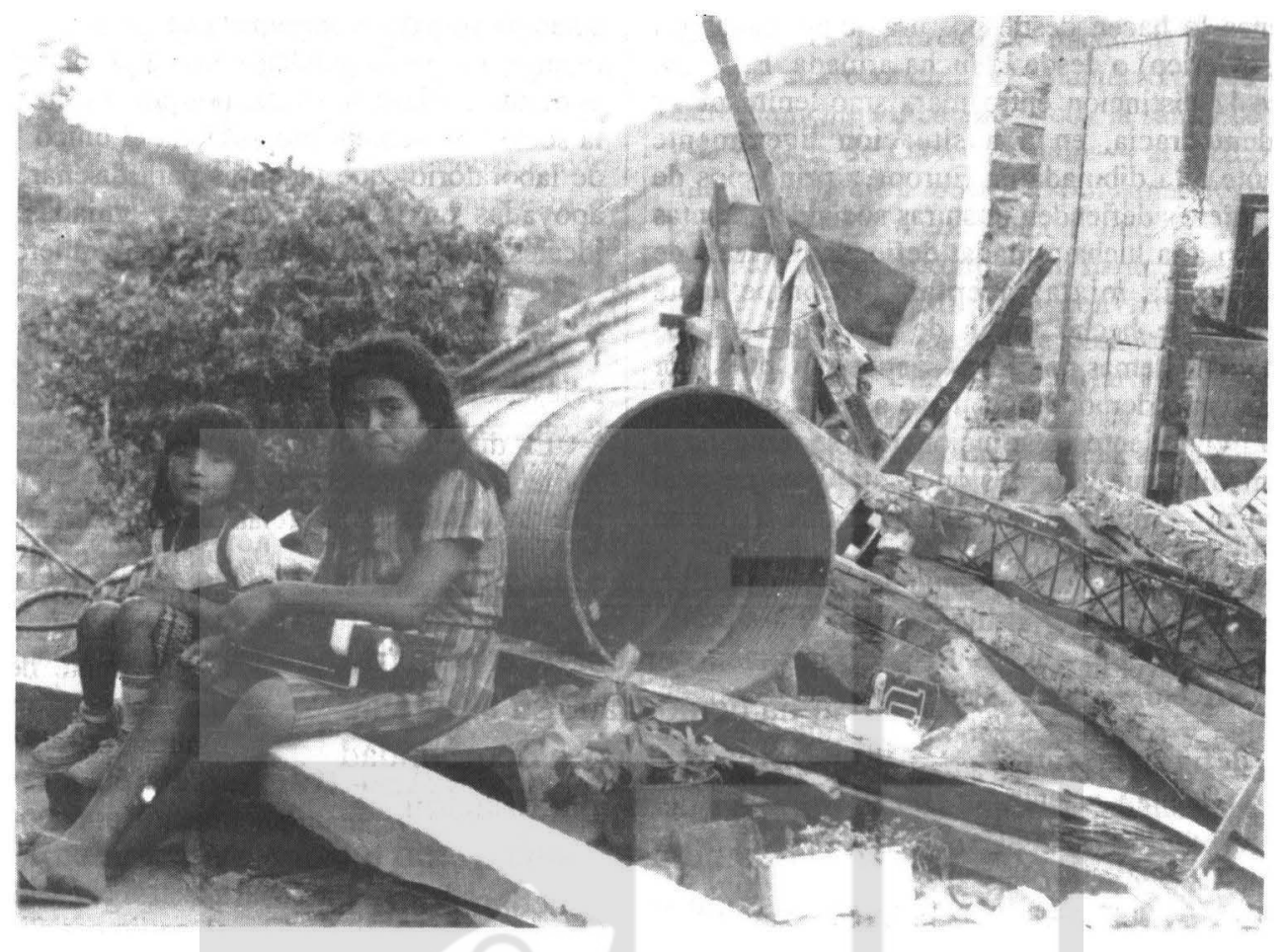

Ello obviamente supuso aceptar las 21 condiciones impuestas pot la III Internacional a sus nuevos miembros, con el subsiguiente abandono -0 paso a segundo plano- de los elementos más polémicos de la visión de la realidad que los socialistas-comunistas latinoamericanos comenzaban a elaborar.

Desde los años treinta hasta los años sesenta, la filiación socialista-comunista no sólo se enfrentó ideológica y políticamente al nacionalismo revolucionario, sino que fue adquiriendo una presencia social y política importante. Consolidada la institucionalidad de partido, se impusieron tanto el formato del partido comunista soviético - partidoJefe = clase obrera - como la aceptación de las tesis dictadas por la III Internacional. A partir de los años sesenta, la filiación socialista-comunista atraviesa por un viraje importante: en ruptura con los partidos comunistas emergen los movimientos revolucionarios armados, con los cuales la relación ortodoxia-heterodoxia en la ideología socialistacomunista hace nuevamente su aparición. El viraje en cuestión tiene relación directa con la revolución cubana y se produce en un contexto en el que emergen las dictaduras militares de los años sesenta y setenta.
Se está ante una nueva fase del socialismocomunismo latinoamericano, misma que añade nuevas características a un modo de hacer política que no por ello pierde algunos de sus rasgos tradicionales. Los rasgos que caracterizan esta nueva fase son los siguientes: creación de una nueva organización de vanguardia, sin abandonar la idea del partido y el centralismo democrático; formación de organizaciones político-militares; conquista del poder estatal que debe realizarse ahora mismo y por la vía armada; aceptación de las tesis básicas del marxismo-leninismo, pero también las tesis de León Trotski (por ejemplo, que la revolución debe extenderse por el mundo) y Mao Tse Tung (por ejemplo, que los campesinos son aliados estratégicos de los obreros). No se olvidan, por lo demás, la tesis de la lucha de clase como motor de la historia, la instauración del socialismo como fase previa del comunismo y que la clase obrera es la clase portadora de la nueva sociedad.

Adicionalmente, a partir de los años sesenta, de manera simultánea a la postulación de la lucha armada como mecanismo de acceso al poder por parte de las nuevas organizaciones marxistaleninistas, aparece una cierta distinción entre quie- 
nes optan por socialismo desde la socialdemocracia y quienes lo hacen desde posturas comunistas (al estilo soviético) o desde la lucha armada. Es decir, aparece la distinción entre marxismo-leninismo y socialdemocracia, en una situación ligeramente semejante a la dibujada en Europa a principios de siglo. Quienes defienden posturas socialdemócratas se oponen a la lucha amada; defienden la tesis de una economía mixta; aceptan la competencia electoral —de hecho tratan de insertarse en sus respectivos sistemas políticos—; apuestan, pues, por un socialismo democrático. Pese a todo, a medida que los movimientos revolucionarios se radicalizan - y a medida que la represión estatal y paraestatal se agudiza - muchos socialdemócratas terminan subordinándose a los grupos revolucionarios, aportándoles fondos y relaciones a nivel intemacional.

En definitiva, entre los años sesenta y setenta se perfilan en la filiación comunista-socialista los siguientes rasgos: cuestionamiento a los partidos comunistas y a su tesis de la "maduración" de las condiciones burguesas; emergencia de grupos político-militares (movimiento armado); y una cierta distinción entre socialismo y comunismo al estilo de la que emergió en Europa a principios de siglo, aunque sin llegar al anatema y a la condena recíproca propios de la experiencia europea.

En los años ochenta se abre paso la discusión sobre la transición a la democracia. Ello supone la aceptación, por parte de la gran mayoría de actores sociopolíticos, de que la democracia (occidental) es algo que conviene lograr. A esas alturas, los movimientos armados o han sido derrotados o están en vías de incorporarse a la "legalidad burguesa". A finales de los ochenta, el derrumbe del bloque del Este y la crisis del marxismo-leninismo ponen en una situación difícil a la filiación socialistacomunista. En ciento modo, en un contexto en el que el socialismo real ha demostrado su absoluta inviabilidad, la poca oportunidad que le queda a la filiación socialista-comunista camina, con todos los reparos que se le puedan poner a la misma, por su vertiente socialdemócrata, porque "al fin y al cabo la socialdemocracia proporciona el único 'material de laboratorio' que tenemos para diseñar políticas apoyadas en la clase obrera y guiadas por los ideales morales tradicionales de la izquierda"4.

\section{Nacionalismo, antiimperialismo y nacio- nalismo revolucionario ${ }^{5}$}

El discurso político latinoamericano ha sido fuertemente influenciado por intelectuales e ideólogos para los cuales o fue relativamente cercana la discusión socialista-comunista (José Ingenieros) o bien se convirtió en un frente de ataque (Haya de la Torre). Tres figuras son claves en la tradición del pensamiento político latinoamericano en la que se sintetiza el nacionalismo, el antiimperialimo y el nacionalismo revolucionario: José Martí (1853-1895), José Ingenieros (1817-1925) y Víctor Raúl Haya de la Torre (1895-1979).

Los dos primeros autores efectúan sus reflexiones teórico-políticas hacia finales del siglo XIX y principios del XX, cuando se agota una forma de ver el mundo y nace una nueva visión de la realidad. No sólo son portavoces del nacionalismo y del antiimperialismo nacientes, sino intelectuales que se plantean a fondo el tema de la cuestión nacional, inseparable de la penetración del capital extranjero en América Latina y del diseño de alternativas para revertir esa dominación imperialista. Como se verá, Ingenieros con su concepto de minorías activas y su rechazo a la mediocridad quiere apuntalar un proceso de transformación social; mientras que Martí le apuesta a las alianzas de clase para construir la identidad nacional. Por su parte, Haya de la Torre, con su

4. M. Cabrera y cols. Evolución y crisis de la ideologia de izquierdas, Caracas, 1993, p. 166.

5. Para una reflexión más específica sobre el nacionalismo latinoamericano ver L.A. González, "El nacionalismo latinoamericano en los umbrales del siglo XXI", ECA, No 555-556, enero-febrero, 1995, pp. 112-116. 
proyecto populista - nacionalista revolucionariopretende integrar a los diversos sectores sociales en torno al Estado, a modo de crear un capitalismo nacional.

(a) José Martí. Este intelectual cubano, considerado por muchos como un lejano antecesor de quienes animaron, como Franz Fanon, los movimientos de liberación nacional africanos en la década de los sesenta y setenta, tiene una actualidad indiscutible. Y ello porque el problema de la independencia y la autonomía latinoamericana sigue presente a finales del siglo XX. Ciertamente, la importancia de Martí no sólo tiene que ver con las posturas políticas que asumió en las diversas coyunturas que llevaron a la independencia de Cuba, sino con el modo cómo se insertó en su contexto histórico: lo hizo como un intelectual, que vinculó su labor periodística, poética y ensayística al proceso de independencia cubano, primero de España y luego de Estados Unidos.

Enviado a España en 1871, como producto de una pena que le fue conmutada, viaja después a México, Guatemala, Venezuela y Estados Unidos. Asimismo, regresa de incógnito a Cuba en 18771878, y ejerce en ese lapso su profesión de abogado. Su actividad política lo lleva al destierro, en 1881, esta vez a Nueva York, lugar donde 'permanece hasta 1895. Ese año regresa a Cuba. Muere en combate el 16 de marzo mientras luchaba por la independencia cubana.

Como pocos latinoamericanos de su tiempo, supo captar la evolución económica de Estados Unidos entre 1880 y 1890 , con sus tendencias a convertirse en un capitalismo monopólico, urbanizado y de expansión militar. Además, supo captar los perfiles socioculturales y políticos de la naciente potencia del norte a finales del siglo pasado. Con razón, no ha faltado quien haya comparado a Martí con Alexis de Toqueville, quien vislumbró las tendencias históricas de Estados Unidos en el siglo XVIII. Por el alcance de sus propósitos y la profundidad de su visión histórica, Martí fue un hombre universal. Pero fue, ante todo, un cubano que vivió con gran intensidad el drama de su país. Participó de ese drama comprometiéndose activamente en lucha por la independencia cubana, razón por la cual fue enviado primero a la prisión y luego al exilio.
Una de sus preocupaciones más acuciantes era explicar los factores que hacen de la economía cubana una economía de plantación, lo cual está estrechamente vinculado - con la salida de Espafia y la llegada de Estados Unidos- al reemplazo de una dominación política por una dominacion económica. La preocupación aludida tiene como correlato un compromiso militante que hace que, desde el exilio, Martí se convierta en el líder intelectual de la guerra de emancipación que se inicia en 1895. Ciertamente, Martí no está solo en su compromiso emancipador; los líderes Antonio Maceo y Máximo Gómez están animados por el mismo espíritu independentista.

Sin embargo, estos últimos insisten en el factor militar como elemento crucial en la lucha liberadora; Martí es más civilista, es decir, en su proyecto se trata de lograr un cambio político. Se trata de lograr la independencia, pero también de romper las estructuras de poder económico y político de las élites locales. Estos cambios son cruciales para poder hacer frente al imperialismo norteamericano. Los objetivos políticos de la lucha independentista se formulan en 1891, cuando se funda el Partido Revolucionario Cubano (PRC), organización que sintetiza los esfuerzos de Martí - vinculando las tareas de propaganda con la actividad de un ejército de liberación nacional- para dar coherencia y eficacia a su proyecto emancipatorio.

En definitiva, Martí fue un ideólogo, un escritor y un propagandista del movimiento independentista cubano. Fue un tipo de intelectual particular, cuya presencia ha sido importante en la historia de las ideas políticas en América Latina. Uno de sus escritos más importantes es Nuestra América $(1871)^{6}$, en el cual aborda el problema de la identidad americana: lo que "quede de aldea en América"; la necesidad de juntar lo diverso; la apuesta por las propias tradiciones sin recurrir a modelos extranjeros; apelar a la "barbarie", ya que lo autóctono es lo que permite hacer frente al agresor externo. Así pues, Martí fue indudablemente un nacionalista, pero fue también un revolucionario que supo articular un proyecto en el que la dimensión nacional corrió pareja con la dimensión antiimperalista. En su propuesta, se tiene que afirmar la nación frente al imperialismo, pero también propiciar un proceso de reforma económica

6. Ver J. Martí. Obras escogidas, La Habana, 1992. 
y política auténticamente nacional. Esto no puede lograrse sin la integración de todos aquellos que comparten la misma tradición. En el fondo, para el prócer cubano - al igual que para Rousseau- se trata de rescatar al "hombre natural", al que hay que reconocer y recuperar. Este es el propósito esencial de la educación; al cumplirlo propicia una sociedad pluralista y diversa, fundada en la igualdad racial, así como en una amplia colaboración entre la clase media, los trabajadores y los indígenas.

(b) José Ingenieros. Este autor sitúa su reflexión en la Argentina influenciada por la presencia del imperialismo inglés en su economía. Es una época en la que su país ingresa a los mercados internacionales de materias primas -exportando carne y trigo- y en la que el mismo experimenta un notable crecimiento demográfico y económico. Entre 1880 y 1914, Argentina se consolida como una sociedad agraria en expansión. Tecnologia, trenes, puertos, finanzas, migración extranjera -italiana y española - dan vida a una sociedad sumamente dinámica. Así, entre 1880 y 1920 , la población asciende de 2.5 millones de habitantes a 9 millones; la superficie cultivable se incrementa de 2.1 millones de hectáreas a 22.3 millones; por último, el comercio exterior se expande de 100 millones de pesos oro a 2 mil millones.

Se está, pues, ante la conformación de una sociedad que será considerada por muchos como el "granero de Inglaterra". Su estrategia de desarrollo está basada en la demanda externa y en inversiones extranjeras localizadas en el sector agroexportador. Por lo demás, la dinámica económica descrita da lugar a una diferenciación social cuyos rasgos más notorios son los siguientes: nuevas funciones estatales centradas en la educación y la salud, crecimiento de la burocracia pública y población migrante en las ciudades $y$, sobre todo, en la capital. Hacia finales del siglo XIX y principios del $\mathrm{XX}$, se configura una estructura social en la cual los terratenientes, los comerciantes, las nuevas clases medias, los trabajadores urbanos y la pequeña burguesía provinciana se convierten en los principales focos de la dinámica social y política.

Es precisamente en este escenario en el que emerge la figura de José Ingenieros. De padres italianos, desde su época de estudiante se involucra en diversas actividades culturales y políticas. Graduado en medicina y derecho, en la universidad participa activamente en política, especialmente en la creación del Centro Socialista Universitario (1894). También participa en la creación del Partido Socialista Obrero Internacional (PSOI), que después pasó a ser el Partido Socialista Obrero Argentino (PSOA).

En 1895 publica su trabajo ¿Qué es el socialismo? en el que expone sus ideas acerca de esa doctrina política, así como sobre la situación argentina y los pasos que tienen que darse para concretar el socialismo tal como él lo entiende. Sus discrepancias con Juan Justo, a la sazón una de las figuras más notables del socialismo argentino y presidente del PSOA, lo llevan a retirarse de la política y dedicarse a la medicina durante la década de 1910 . Se integra a la Universidad de Buenos Aires como catedrático de medicina legal, hasta que el Presidente argentino Sáenz Peña se niega a ratificarlo en su cargo a finales de la década. Según sus biógrafos, Ingenieros se inspira en esta experiencia para escribir, en Europa, El hombre mediocre, publicado en 1914.

De nuevo en su país, a partir de 1914, el trabajo intelectual de Ingenieros se vincula a los temas filosóficos. Funda la Revista de Filosofia y trabaja en su libro La evolución de las ideas argentinas. De esto se ocupaba cuando tiene lugar el movimiento estudiantil de Córdova al que se adhiere con entusiasmo. Además de la reforma universitaria, dos acontecimientos impactan a Ingenieros: la revolución bolchevique -a la que defiende apelando a la solidaridad y justicia social de la que 
la misma es portadora- y la primera guerra mundial.

En su último año de vida (1925) participa, junto con Ortega y Gaset, Haya de la Torre y Miguel Angel Asturias, en la Asamblea Antiimperialista celebrada en París. En seguida viaja a México, donde lo recibe el presidente Plutarco Elías Calles. Regresa a Buenos Aires, donde muere a finales de ese año.

¿Cuáles son las ideas de Ingenieros?'. Un tema central en su pensamiento es la cuestión social. Parte de la constatación de que el capitalismo genera miseria e injusticia social. Sin embargo, eso no lo hace inmoral por definición; lo que tiene son aspectos negativos, que son precisamente los que deben reformarse. Entre estos aspectos negativos están el deterioro de los salarios, las inhumanas condiciones de vida de los obreros, el consumo ostentoso de las élites dominantes y la acumulación sin límites de capitalistas y oligarcas. Ante esto, se tiene que proponer un modelo moral que traerá como resultado la implantación de formas distributivas del excedente económico que beneficien a los grupos sociales mayoritarios. Otra medida insoslayable es el control del parasitismo de los grupos pudientes de la sociedad. De lo que se trata, pues, es de limitar los efectos nocivos del capitalismo y no de su erradicación.

El legado anarquista es importante en Ingenieros, como se nota en su idea de que existe una oposición tajante entre el productor - que vive de su trabajo- y el parásito - que vive del trabajo de otro. Esta influencia también se hace sentir en el Partido Socialista Obrero, cuyos rasgos característicos son los siguientes: la movilización social se funda en la organización sindical de los trabajadores; los sindicatos deben luchar por mejorar las condiciones de vida de los obreros; un frente de la lucha sindical es el parasitismo de los propietarios; los productores deben reemplazar a los parásitos; el trabajo y la producción son parte de una misma ética libertaria que conducirá a la emancipación de los empobrecidos. El socialismo es, para Ingenieros, "el más noble de los ideales que han agitado a la humanidad y el más justo de los pabellones que los oprimidos enarbolan,

Irameando al impulso del arma voluptuosa de la libertad, bajo los rayos regeneradores de la ciencia y el progreso".

Adicionalmente, Ingenieros introduce la noción de minorías activas, cuyo papel es clave en la elaboración de su proyecto de transformación social. Esas minorías, que tienen acceso al conocimiento, a saber, a la ciencia, constituyen una secta con talento que debe influir en el cambio social. Es el hombre de conocimiento - al margen de las ideologias y de las prácticas burocráticasel que debe dinamizar la transformación social. Se trata de vincular conocimiento y trabajo; intelectuales y proletarios deben aliarse para superar el parasitisimo y la mediocridad. Es decir, mérito y ciencia deben ponerse a favor de los oprimidos, porque el saber libera cuando opera políticamente. Sólo tienen mérito los que se han preparado; sólo ellos pueden legítimamente conducir a la sociedad. La política es asunto de sabios y no de una clase que domina a base de la exclusión. "La cuna dorada no da aptitudes; tampoco las da la cuna electoral". En fin, el lema de Ingenieros es que los que saben deben dirigir a los que no saben.

En su perspectiva, se trata de reivindicar al intelectual independiente, que destaca por sobre la minoría oligárquica y por sobre la masa popular: ambos son proclives a la mediocridad. El intelectual independiente es el portador de unos nuevos valores en los cuales la sabiduría ocupa un lugar privilegiado. El portador de los mismos es el inmigrante europeo, pues no se puede negar que la "superioridad de la raza blanca es un hecho aceptado hasta

7. Ver J. Ingenieros, Antiïmperialismo y nación, México, 1979. 
por los que niegan la existencia de la lucha de razas. La selección natural tiende a extinguir a las razas de color". La propuesta de Ingenieros es construir la identidad americana en los migrantes, quienes están más capacitados para asumir el rol de minorías activas.

Al final de su vida, este autor argentino insiste - a la manera de G. Sorel- en la vinculación entre lo espiritual y lo voluntario; la inspiración moral y el compromiso político. En la línea de E. Durkheim, insiste en la necesidad de crear una solidaridad colectiva como fundamento de un orden social estable, regido por normas y leyes morales y sociales. Con esto es consecuente con su propósito de reformar moralmente al capitalismo. Después del cambio moral, vendrá el cambio político, económico y social.

(c) Víctor Raúl Haya de la Torre. Este intelectual y líder político peruano, se vinculó desde muy joven a la lucha estudiantil. Su actividad política universitaria lo llevó al exilio, concretamente a México, donde estuvo desde 1923 hasta 1926. En este país formula la propuesta de la Alianza Popular Revolucionaria Americana (APRA), tan importante en la historia del populismo latinoamericano. Viaja a la Unión de Repúblicas Socialistas Soviéticas -donde se familiariza con el marxismo-leninismo- y a Inglaterra -donde estudia con el autor de la Historia del pensamiento socialista, D.H. Cole.

A pesar de que en sus primeros años de militancia compartió experiencias con Mariátegui, Haya de la Torre se distancia desde un principio de la filiación marxista. Ciertamente, se sirve de muchas de sus nociones para interpretar la realidad peruana, pero lo hace siempre con una intención contraria a la que cabría esperar de un socialista-comunista; se trata en la propuesta de Haya de la Torre de potenciar un capitalismo latinoamericano, y no de establecer un régimen socialista como antesala del comunismo. Su pregunta, como la de tantos intelectuales de su época, es por la naturaleza de América Latina: ¿qué es América Latina? ¿Cuáles son sus actores sociales fundamentales? ¿En qué dirección deben avanzar sus transformaciones socioeconómicas y políticas? Con estas inquietudes en mente, este autor peruano se apresta a dar su aporte al debate político latinoamericano ${ }^{8}$.
Su experiencia en Perú, conjugada con los conocimientos que adquiere en su estadía europea, lo llevan a caracterizar a América Latina como un feudalismo colonial. Haya de la Torre está convencido de la inexistencia de un capitalismo consolidado en la región; lo que existe de éste es apenas muy incipiente y sin capacidad de desarrollo autónomo debido a la presencia del imperialismo. En América Latina, según él, hay imperialismo sin capitalismo, pues el primero vive a expensas de la herencia feudal colonial que le es imprescindible para sus fines. En un afán que incluso lo llevó a sentirse como quien había superado con creces a Lenin, Haya de la Torre afirmó que en América Latina el imperialismo no es la fase superior del capitalismo, sino la primera. Se trataba, por tanto, de llevar adelante una lucha antiimperialista y antifeudal, pero con el proposito de instaurar un capitalismo nacional.

En este proyecto -que fue en definitiva el proyecto de la APRA - no tenía cabida la noción de las clases sociales y su lucha. En lugar de ello había que potenciar la creación de una amplia alianza multiclasista, liderada por las clases medias y forjadora de un Estado fuerte capaz de propiciar el surgimiento de una auténtica burguesía nacional. Esta visión, en la que se rechaza el conflicto de clases como eje dinamizador del desarrollo social, se sitúa en la línea de un Estado benefactor, que debe ser lo suficientemente fuerte tanto para promover el desarrollo de la industria nacional como para hacer frente al imperialismo.

En resumen, como sostiene F. Zapata, "en la propuesta de Haya de la Torre se afirma que el desarrollo de indoamérica es diferente al europeo. En América Latina existe un feudalismo colonial que impide el desarrollo de una burguesía autóctona, que implica que este feudalismo coexista con el capitalismo que, a su vez, se identifica con el imperialismo. Esto da lugar a la afimación según la cual 'el imperialismo es la primera etapa del capitalismo en América', que contradice la tesis de Lenin en cuanto a que éste la identifica con la última etapa. Políticamente, la existencia de este tipo de articulación entre el faudalismo colonial y el imperialismo da pie a la imposibilidad de separar la lucha antiimperalista de la lucha antifeudal... Se trata entonces de constituir una alianza o frente

8. Ver V. R. Haya de la Torre, ¿Qué es el APRA?, México, 1924; El antiimperialismo y el APRA, México, 1979. 
único de todos estos grupos - presentes en la sociedad feudal colonial-, independientemente de su adscripción de clase, que se proponga la constitución de un Estado antiimperialista cuyo núcleo esté formado por los grupos medios que son los más lúcidos y conscientes de dicha dominación"9.

El proyecto aprista tuvo un éxito político indudable. Como el modelo que surgió en México, inmediatamente después de la revolución de 1910, fue una síntesis del nacionalismo y el antiimperialismo, es decir, fue un nacionalismo revolucionario. Los regímenes populistas que dominaron la vida política latinoamericana desde los años treinta hasta los sesenta tuvieron en el proyecto de la APRA una fuente de inspiración decisiva. Haya de la Torre fue el gestor de esa propuesta en virtud de la cual los Estados latinoamericanos propiciaron el desarrollo industrial, la organización de la sociedad civil y la creación de sistemas políticos incipientemente democráticos. Lo que se ha dado en llamar la matriz estado céntrica ${ }^{10}{ }^{11}$ tuvo en Haya de la Torre a uno de sus principales artífices intelectuales. Esa matriz entró en crisis con el advenimiento de las dictaduras militares de los años sesenta y setenta, las cuales dieron inicio a un proceso inexorable de redefinición del Estado. Las actuales propuestas de limpiar la economía de cualquier presencia estatal son parte de la ofensiva antiestatista que militares como Pinochet iniciaron en $1973^{12}$. Las reformas neoliberales están llevando a término la obra iniciada por los militares; con ello, están tirando por la borda lo que quedaba de la propuesta sociopolítica de Haya de la Torre.

\section{La tradición socialista-comunista latinoame- ricana}

En el discurso socialista-comunista latinoamericano se pueden distinguir tres grandes fases: la fundacional, dominada por figuras de la talla de Luis Recabarren (1876-1924), Julio Antonio Mella (1903-1929) y José Carlos Mariátegui (1894-1930); la fase dominada por los partidos comunistas (19301959); y la que arranca a partir del triunfo de la revolución cubana y el desarrollo de los movimientos de la liberación nacional (1959) ${ }^{13}$.

Los tres intelectuales aludidos comparten, como característica común, el esfuerzo por "nacionalizar" las tesis del marxismo que habían logrado asimilar en aquel entonces. Recabarren ${ }^{14}$ lo hace en un país, Chile, donde la presencia de los sindicatos mineros es dominante, al igual que son dominantes las prácticas políticas de tipo parlamentario. Como periodista y educador revolucionario, su interés es hacer de la lucha sindical un instrumento de reforma socioeconómica que no deseche los canales institucionales establecidos. La organización de los trabajadores, el partido, no debe reemplazarlos en la lucha, sino orientarlos y encauzar las energías sindicales. Mella ${ }^{15}$, en una dirección distinta aunque no totalmente ajena a la de Martí, quiere la emancipación de Cuba. Pero en Mella esa emancipación pasa por la lucha de clases y por el protagonismo de la clase obrera y el partido comunista. Estos son los propósitos que lo animan en la Universidad de la Habana, desde donde alimenta el compromiso estudiantil con la revolución. Mariátegui ${ }^{16}$-quizás el más universal de los marxistas latinoamericanos

9. F. Zapata, op. cit., p. 102.

10,11. Ver L. A. González, "Estado, mercado y sociedad civil en América Latina", ECA, No. 552, octubre de 1994, pp. 1045-1056; M. Cavarozi, "Más allá de las transiciones. Reflexiones sobre el largo plazo en la política latinoamericana". En C. Barba Solano, J. L. Barros y J. Hurtado (Comps.), Transiciones a la demiocracia en Europa y América Latina, México, 1991, pp. 387-402.

12. Ver L. A. Gonź́lez, "Los militares latinoamericanos”, ECA, No 564, octubre de 1995, pp. 1011-1016; A. Rouquie, El Estado militar en América Latina, México, 1984.

13. Ver M. Lowi, El marxismo en América Latina (de 1909 a nuestros días), México, 1982; R. Fornet Betancour, $O$ marxismo na America Latina, Sao Leopoldo, 1995.

14. Ver L. E. Recabarren, "La revolución rusa y los trabajadores chilenos", 1921. En M. Lowi, El marxismo en América Latina (1909 a nuestros dias), México, 1982; A. Angell, Partidos políticos y movimiento obrero en Chile. De los orígenes hasta la Unidad Popular, México, 1974.

15. Ver J. A. Mella, La guerra de clases en Cuba, 1926; El proletariado y la liberación nacional, 1928. En M. Lowi, op. cit.

16. Ver J. C. Mariátegui, El problema indígena en América Latina, 1929; La revolución socialista latinaamericana, 1929. En M. Lowi, op. cil. 
en el siglo $\mathrm{XX}$ - introduce una reflexión de tipo cultural para entender la formación social peruana de la época. Su formación en el marxismo italiano le permite valorar la complejidad de la cultura - como es el caso del Perú con su población indígena- y su importancia para el cambio social.

De los tres, quien más cerca está de la tradición posterior, dominada por los partidos comunistas, es Mella. Pero ello sólo en parte, pues el marxismo de Mella está comprometido -en la línea de Trotski- con "el triunfo en cada país de la revolución obrera sobre el imperialismo mundial". Los otros dos más bien llegan a sostener relaciones difíciles y tensas con los aparatos partidarios que no tardan en manifestar, a la par de rasgos burocráticos marcados, su sumisión a las directrices de la Internacional Comunista. Con todo, ellos son los exponentes más notables del marxismo funcional latinoamericano, en el que predominan la creatividad y el esfuerzo personal para comprender la realidad que les tocó vivir. No existe un esquema al que todos deban adscribirse; tampoco existe una censura partidaria que ponga límites a los esfuerzos intelectuales que ellos realizan.

En buena medida, esta situación se explica por la misma coyuntura comunista intemacional. En efecto, si nos situamos en los años 1920-1923, la efervencencia revolucionaria en Rusia está en pleno auge, las tesis trotskistas acerca de la revolución mundial no han sido descartadas y no se ha impuesto la concepción de socialismo en un sólo país. Dos documentos de la Internacional Comunista de esa época confirman esta apreciación. En el primero, "Sobre la revolución en América" (1921), se discuten, entre otros temas, el vasallaje de América Latina hacia el imperialismo norteamericano; la explotación de los pueblos latinoamericanos por los explotadores nacionales; y la necesidad de una alianza de obreros y campesinos para liberar a los pueblos latinoamericanos de la opresión nacional e imperialista, alianza que debe ser amplia: obreros, campesinos, revolucionarios de Estados Unidos y la Internacional Comunista. "Las masas de América Latina - dice el escritodeben adquirir su lugar en el ejército de la 'revolución mundial"”

En el segundo documento, A los obreros y campesinos de América del Sur (1923), firmado por el IV Congreso de la Internacional Comunista, realizado con motivo del V Aniversario de la revolución rusa, se hace un llamado a prepararse para la lucha de clases y la acción revolucionaria del proletariado mundial. Asimismo, se señala que América del norte (Estados Unidos) es el centro de la reacción internacional de la burguesía contra el proletariado, por lo cual la lucha de todos los proletarios de América -incluidos los de Estados Unidos- es una necesidad imperiosa. Luchar contra la propia burguesía es luchar contra el imperialismo yanki que encama a la reacción capitalista mundial. El ejemplo heroico de esta lucha es la revolución rusa, que se enfrenta encamizadamente al capitalismo internacional. En resumen, el documento concluye con las siguientes expresiones: “ $i$ Viva la Internacional Sindical Roja!, ¡Viva la Internacional Comunista!, ¡Viva la Rusia de los Soviets!, ¡Viva el proletariado revolucionario de América!, ¡Viva la revolución mundial!".

Curiosamente, este espíritu revolucionario que predomina en los círculos comunistas en los primeros años de la década de los veinte, está presente en el movimiento comunista salvadoreño de los años treinta, cuando, en Moscú, el ascenso de Stalin ha puesto en franco retroceso las tesis de la revolución mundial —que han sido reemplazadas por la de los frentes populares antifacistas - y ha impuesto la tesis del socialismo en un solo país, lo cual ha sido aceptado por la mayor parte de las élites comunistas europeas.

Si se revisa la documentación del Partido Comunista Salvadoreño sobre los sucesos de 1932, en la misma está presente la idea de que la revolución es una tarea que no se puede posponer, pues la hora del socialismo ha llegado. En una terminología tomada de la época heroica de la revolución rusa, se sostiene que los obreros, campesinos y soldados - dirigidos por el Comité Militar Revolucionario- son los que harán la revolución. Es decir, se trata de hacer una revolución proletaria que, bajo la conducción del Partido Comunista, lleve al poder a los obreros, campesinos y soldados. En consecuencia, uno de sus lemas más queridos es el que dice: “¡Viva el ejército Rojo en el cual el soldado tendrá los derechos del hombre y no será un esclavo como en el ejército manejado por los ricos!". Este espíritu combativo está recogido en una credencial de las usadas por los comunistas durante la revuelta de 1932. 
"Credencial de Comandante Rojo" PCS

Sección de la Internacional Comunista Comité Central

Este Comité Central nombra al camarada Inocente Rivas Hidalgo comandante rojo de las fuerzas que operarán en la zona $y$ en la toma de la ciudad de San Salvador, quedando bajo su absoluta responsabilidad la marcha de la lucha revolucionaria hasta el triunfo final contra la clase explotadora. Extendida en el Cuartel General del Ejército Rojo de El Salvador a los 16 días del mes de enero de 1932.

Por la destrucción implacable de la burguesía nacional y el imperialismo. Por el Comité Central. El Secretario General Interino. Octavio Rodríguez

Así pues, el Partido Comunista Salvadoreño se inscribe en la oleada del comunismo ruso anterior a la llegada de Stalin al poder. Hacia 1930, éste ya ha llevado adelante varias depuraciones de la vieja guardia del ejército rojo $y$ ha difundido la tesis del socialismo en un solo país con la que desautoriza a Trotsky, posteriormente asesinado en México (1940). El viraje dado por Stalin repercute directamente en la mayoría de partidos comunistas, puesto que la Intemacional Comunista - plegada totalmente a los intereses estalinistas - comienza a incididir de forma decisiva en los planteamientos de las organizaciones que se han adscrito a ella.

A partir de los años treinta, comienzan a proliferar los Partidos Comunistas en América Latina, y su formato organizativo es copiado, casi mecánicamente, del formato del PCUS: un Secretario General, situado en la cúspide del poder partidario; un Comité Central, subordinado al primero; y los militantes de base, encargados de hacer cumplir los dictados emanados desde la cima del partido ${ }^{18}$. Sus planteamientos ideológicos, rígidos y simples en sus supuestos doctrinarios, varian en la práctica según las directrices de la III Internacional. ¿Cuáles son los supuestos doctrinarios? La lucha de clases como motor de la historia, la inevitabilidad del socialismo y el comunismo, el protagonismo de la clase obrera y el papel del Partido Comunista como organización dirigente por excelencia ${ }^{19}$.

En el plano práctico, el primer viraje de los partidos comunistas latinoamericanos de América Latina respecto de la tesis de la lucha frontal contra la burguesía y el imperialismo se produce hacia 1935, cuando la tesis de los frentes populares comienza a tomar vigencia con el subsecuente rechazo a las ideas trotskistas que la misma supone. Este es el caso del Partido Comunista Chileno en 1938, que en el texto El frente popular en Chile, firmado por su Secretario General, Carlos C. Labarca, sostiene que la lucha revolucionaria es una lucha por las "libertades democráticas" y en contra de la reacción imperialista que ha tomado la forma de fascismo. Según este documento, para llevar adelante esa lucha se requiere de una alianza en la que tengan presencia los comunistas, los católicos, ciertos grupos burgueses y los intelectuales. Además, se trata de tener una política de "buena vecindad" con Estados Unidos, lo cual supone que la legalidad debe ser respetada por todos los que, en la lucha contra el fascismo, han apostado por la democracia.

El Partido Comunista Cubano, en 1939, se encamina por la misma dirección. Incluso en el III Congreso del partido se llega a ver en Fulgencio Batista a un defensor de las tendencias progresistas y democráticas que, como cabeza del Frente Fascista Americano en formación, es atacado por la reacción fascista. El Partido Comunista Argentino, en 1939, también se inscribe en esta tendencia, tal como queda de manifiesto en el libro de Ernesto Giudici El imperialismo y la liberación nacional (1940). Para este dirigente comunista, lo políticamente reaccionario - el fascismo- debe ser barrido por la democracia que florecerá con el ascenso de las fuerzas jóvenes, progresistas y revolucionarias. Demócrata es el gobiemo que se apoya en las grandes masas contra las oligarquías reaccionarias. En América Latina, la democracia no podrá implantarse de golpe, puesto que se requieren condiciones

17. Ver Documentos del Partido Comunista de El Salvador, 1932. En M. Lowi, op. cit.

18. E. H. Carr, Historia de la Rusia soviética. La revolución Bolchevique (1917-1923). I. La conquista y la organización del poder, Madrid, 1985.

19. Por cierto que estos supuestos tuvieron una amplia difusión en los manuales de marxismo-leninismo elaborados $\longrightarrow$ avalados - por la Academia de Ciencias de la Unión de Repúblicas Socialistas Soviéticas. 
económicas y sociales básicas para ello. Lo que es más importante: la democracia política requiere de la formación de una burguesía nacional liberal. Por lo demás, la masa popular es consciente de que no puede haber lucha antiimperialista - antifascistasin lucha correlativa por la democracia; y esta última debe dar cabida a amplios sectores de la población que quieran comprometerse en ella.

El Partido Comunista Mexicano, en 1945, sigue por el mismo camino. En el documento Voz de México celebra el pacto de unidad nacional establecido entre la Central de Trabajadores de México (CTM) y la Confederación de Cámaras Industriales. Según los comunistas mexicanos, el pacto no ś́lo es para contribuir a una unidad nacional de largo alcance, sino que recoge el clamor de los patriotas de México que lanzaron la idea de la unidad nacional desde que fue lanzada la brutal guerra de conquista de los hitlerianos y desde que el mundo se lanzó contra los bandidos nazis. Antes, en el IX Congreso del Partido Comunista Mexicano (mayo de 1984), el Secretario General del partido, Dionisio Encina, habia dicho: "afirmamos que lo que se halla a la orden del día es la independencia y el progreso de México. Declaramos que, enmarcados en ese cauce, es posible e indispensable que todos los sectores, clases, grupos y fuerzas de la nación, todos los hombres de las diversas ideologías o creencias se unan alrededor de su objetivos comunes y sean firmes defensores de esta unidad nacional".

En resumen, según el texto aludido arriba, el Partido Comunista Mexicano apuesta por la perdurabilidad de la alianza obrero-empresarial. Para ello, se tienen que crear comités tripartitos (gobiemoempresarios-rabajadores) que resuelvan los problemas de las fábricas y que permitan una armonía laboral en vistas a facilitar la inversión extranjera, especialmente la proveniente de Estados Unidos.

Por último, tenemos el caso del Partido Comunista Brasileño que en la Declaración sobre la política del Partido Comunista en Brasil, en 1958, plantea claramente el tema de la "vía pacífica de la revolución". La tesis fuerte del Partido Comunista Brasileño es que el desarrollo capitalista corresponde a los intereses de todo el pueblo, por lo que la contradicción principal es la que existe entre la "nación en desarrollo" y el imperialismo norteamericano. En el caso de Brasil, se nos dice, la revolución no es primero socialista, sino antiimperialista y antifeudal, nacional y democrá- tica. Si el desarrollo económico esté en contradicción con la explotación imperialista norteamericana, ¿cómo oponerse a esta última? Creando un "frente único" que luche por un gobiemo nacionalista $y$ democrático. Ello exige que el proletariado se una con la burguesía, para así luchar juntos por un desarrollo independiente y progresista. Por supuesto, el proletariado debe salvaguardar su especificidad ideológica y política en el interior del frente único, aunque cuidándose de que la salvaguarda de sus propios intereses no conduzcan a una ruptura con la burguesía.

Que lejos se encuentran los planteamientos de los partidos comunistas examinados de las ideas que animaron al movimiento revolucionario en los años veinte. Aunque aparentemente imperceptible, el influjo de la III Internacional $y$, con ella, de los intereses soviéticos es indudable. Primero, muy a tono con la pretensión de Stalin de consolidar el modelo soviético — socialismo en un solo país- y de eliminar a sus posibles adversarios, los partidos comunistas latinoamericanos retroceden respecto de las ideas de la revolución permanente. Segundo, en los años treinta y en el marco de las purgas estalinistas, emerge la amenaza fascista en Europa que es asumida, primero sólo de manera retórica y después en serio cuando estalla la segunda guerra mundial, como bandera de lucha por Stalin y de quienes se pliegan a sus designios: los partidos comunistas latinoamericanos, al seguir las directrices de la Internacional Comunista, hacen suya la bandera antifascista, sacan a Estados Unidos de la mira de sus ataques - que en forma súbita se convierte en un aliado- y colocan a Alemania en su lugar, de manera simultánea proclaman la necesidad de una alianza antifascista en la que tiene cabida la burguesía, que doctrinariamente todavía constituye la enemiga irreconciliable de la clase obrera. Tercero, después de la segunda guerra mundial -en que la necesidad de un frente popular es proclamada con vehemencia por los comunistas - y una vez que se ha disipado el peligro de la Alemania nazi, en el discurso de la Intemacional Comunista aparece de nuevo Estados Unidos como el enemigo de la revolución. Los partidos comunistas, con la mayor facilidad, aunque conservando la terminología de los frentes populares e incluyendo a la burguesía en sus propósitos transformadores, hacen suyo ese cambio de objetivo.

En resumen, entre 1930 y 1960, los partidos 


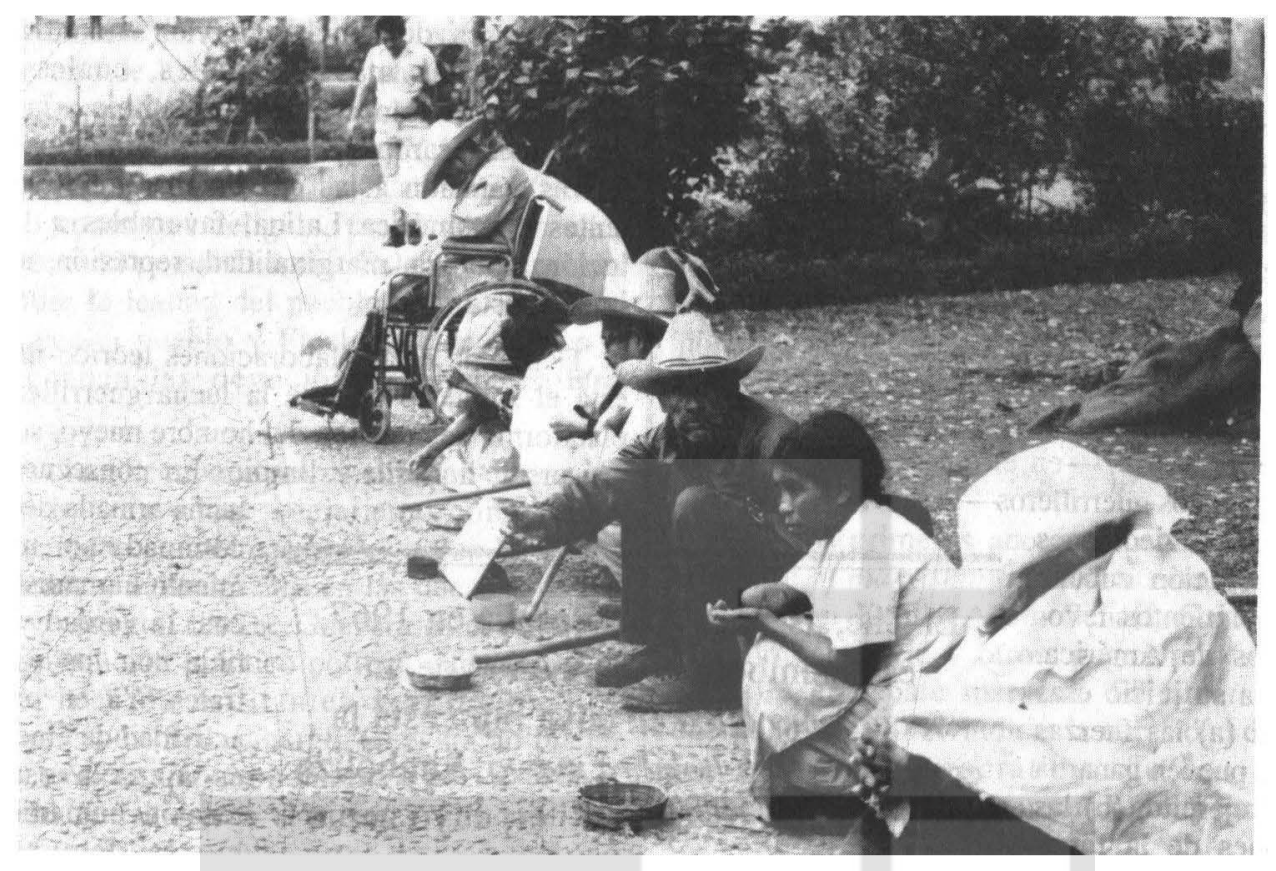

comunistas latinoamericanos institucionalizan una práctica política cuya doctrina tiene poca relación con el modo en que se insertan en la realidad que les toca vivir. Se impone en la práctica la idea de las etapas: para llegar al socialismo y al comunismo -doctrinariamente inexorables - se tienen que crear las condiciones democrático burguesas que hagan posible ese salto. De esta manera se está ante una heterodoxia respecto de las tesis defendidas por los revolucionarios rusos, Lenin y Trotsky, quienes, a su vez, fueron heterodoxos respecto de Marx al plocamar la revolución en uno de los países capitalistas más atrasados.

En la década de los cincuenta, la relación ortodoxia-heterodoxia resurge con fuerza en los círculos de la izquierda comunista latinoamericana. Surge una nueva heterodoxia: la representada por la revolución cubana y los movimientos armados de liberación nacional. Ambos experiencias suponen una cierta ruptura con las tesis defendidas por los partidos comunistas, incluso, en muchos aspectos, se vuelve a la ortodoxia rusa de principios de siglo: la revolución no sólo es una tarea del presente, sino que la misma debe tener un alcance internacional. Se impone la idea de que la estrategia de la lucha armada (guerrillera) es la que se debe privilegiar sobre otras formas de lucha; asimismo, surge una nueva vanguardia de naturaleza político militar, articulada por núcleos armados y regida en muchos casos por el centralismo democrático. Su base de sustentación social son los sectores oprimidos, especialmente los obreros y los campesinos, quienes deben aliarse para luchar por la transformación social.

La lección de la revolución cubana a los partidos comunistas se puede resumir así: estos últimos han buscado el socialismo siguiendo una ruta equivocada, pues la ruta correcta es la lucha armada, a la cual tienen que sumarse si quieren ser protagonistas en el proceso revolucionario. Por la lucha armada, el socialismo y el comunismo se revelan como ideales realizables aquí y ahora no por burócratas regordetes y acomodados, sino por guerrilleros sacrificados y heroicos como Ernesto "Che" Guevara $^{20}$.

20. La experiencia cubana, en general, y la experiencia de Guevara, en particular, encontraron en Regis Debray a uno de sus portavoces más activos. Este autor alabó con un entusiasmo sin límites La crítica de las armas de la que era expresión la revolución cubana, así como la Revolución en la revolución que ella había operado, 
El Che, asesinado en Bolivia en 1967, es el símbolo emblemático de un socialismo ético en cuya mira está la creación de un hombre nuevo ${ }^{21}$. Simboliza también al estratega militar, cuyo genio se plasmó tanto en el campo de batalla como en textos destinados a difundir sus enseñanzas guemeras. Dos escritos sobresalen en este punto: La guerra de guerrillas (1961) y Guerra de guerrillas, un método $(1963)^{22}$, claves en la difusión de la estrategia guerrillera en la mayor parte de América Latina a partir de la experiencia cubana. En el primer escrito —en el que se fundamenta la tesis de los focos guerrilleros-, Guevara se interesa por exponer las lecciones de la revolución cubana a los movimientos revolucionarios de América. Tres son a su juicio esas lecciones: (a) las fuerzas populares pueden ganar la guerra al ejército; (b) las condiciones de la revolución pueden ser creadas por el foco insurreccional; y (c) el terreno de la lucha armada es el campo. Los dos primeros aspectos están encaminados a rechazar a los "quietistas" revolucionarios o pseudorrevolucionarios. El tercero encierra una crítica a los dogmáticos que apuestan por la ciudad.

En el segundo escrito, Guevara se pregunta qué es la guerra de guerrillas y cuál es su utilización correcta. Sus ideas al respecto son las siguientes: la guerra de guerrillas es una guerra del pueblo, es una guerra de masas; la guerrilla es la vanguardia del pueblo, situada en un lugar determinado de algún territorio dado. Desarrolla una serie de acciones bélicas tendientes a un fin estratégico: la toma del poder, para lo cual se apoya en los campesinos y obreros. Siguiendo a Lenin, el Che afirma que no se debe temer a la violencia, que es la partera de sociedades nuevas. La violencia revolucionaria debe desatarse en el momento preciso, es decir, en el momento en que los conductores del pueblo hayan encontrado las circunstancias más favorables, cuales son la conciencia de la necesidad del cambio y la certeza de que ese cambio es posible (condiciones subjetivas), aunado a las condiciones objetivas existentes en América Latina, favorables a la revolución: pobreza, marginalidad, represión, agresión imperialista.

Detrás de estas elaboraciones teórico militares, está el supuesto de que la lucha guerrillera es la plataforma de creación del hombre nuevo, solidario, universal, honesto y limpio. En consecuencia, la lucha armada debe estar dominada por un sentimiento humanista, en el cual la verdad y la justicia son los ejes centrales. Ya en poder, la actividad de Guevara no es ajena a esta pretensión humanista, como lo demuestra su defensa de la libertad ideológica de los trabajadores en el texto Contra el sectarismo (1961). Mientras que en el documento El cuadro columna vertebral de la revolución (1963) defiende la igualdad civil y la dignidad de los trabajadores, al tiempo que apuesta por un desarrollo político de los cuadros revolucionarios que tiene que ver no sólo con el aprendizaje del marxismo, sino también con la responsabilidad individual por los actos que cada uno realiza. Se trata de un socialismo ético, antiburocrático, que resalta la responsabilidad individual por encima de la sujeción impuesta por el partido. "El revolucionario cabal, el miembro del partido dirigente de la revolución debería trabajar a todas horas, todos los minutos de su vida con un interés siempre renovado y siempre creciente y siempre fresco".

Estamos, pues, ante un planteamiento humanista que resalta el respeto a la individualidad y a los méritos de cada persona. Pero Guevara no termina

aunque poco después puso reparos a su interpretación original de la lucha armada. Ver $\mathbf{R}$. Debray, La crítica de las armas, México, 1975. Sobre la actividad de Guevara en Bolivia, R. Debray, La guerrilla del Che, Mérico, 1975.

21. Ver E. Guevara, El socialismo y el hombre nuevo, México, 1979.

22. En Emesto Che Guevara, Obras escogidas 1957-1967. La Habana, 1991, Vol. I. 
de ser totalmente coherente con su posición, puesto que él es uno de los que alimentan la idea de que Fidel Castro es el Jefe revolucionario identificado totalmente con el pueblo cubano ${ }^{23}$. Hablando de Camilo Cienfuegos, dice el Che: "Camilo practicaba la lealtad como una religión, era devoto de ella; tanto la lealtad personal hacia Fidel, que encarna como nadie la lealtad del pueblo, como la de ese mismo pueblo; pueblo y Fidel marchan unidos y así marchaban las devociones del guerrillero invicto".

La revolución cubana marca el punto de partida de la última fase del socialismo-comunismo latinoamericano que parece agotarse con los casos nicaragüense y salvadoreño en las décadas de los ochenta y noventa. El Che Guevara es el portavoz de una orientación práctico política que renovó el quehacer de los militantes revolucionarios latinoamericanos. Sin embargo, Guevara no fue un marxista teórico, sino un hombre de acción. Por el lado de la teoría, quizás el mejor y último exponente del socialismo-comunismo latinoamericano es Adolfo Sánchez Vázquez, español que llegó a México en 1939, a la edad de 23 años, y asumió, desde ese entonces, los retos y problemas de América Latina.

Miembro de la Juventud Comunista, luchó en la guerra civil española. Ante la derrota de la República se acogió al asilo ofrecido por Lázaro Cárdenas a los españoles -intelectuales en su mayoría - que se vieron forzados a abandonar su país. En una primera etapa —durante la guerra civil y en sus primeros años en México-, Sánchez Vázquez fue más un militante que un filósofo - se doctoró en 1966 con su tesis Sobre la praxis-, y para él tenían validez las tesis clásicas del marxismo-leninismo recogidas en el Diamat soviético. En un segunda etapa, Sánchez Vázquez se ve influenciado por el proceso de desestalinización emprendido por Nikita Kruschef en el marco del XX Aniversario del Partido Comunista de la Unión Soviética, en 1956. A esto se añaden la invasión a Checoslovaquia por las tropas del Pacto de Varsovia (1968) y el triunfo de la revolución cubana (1959).

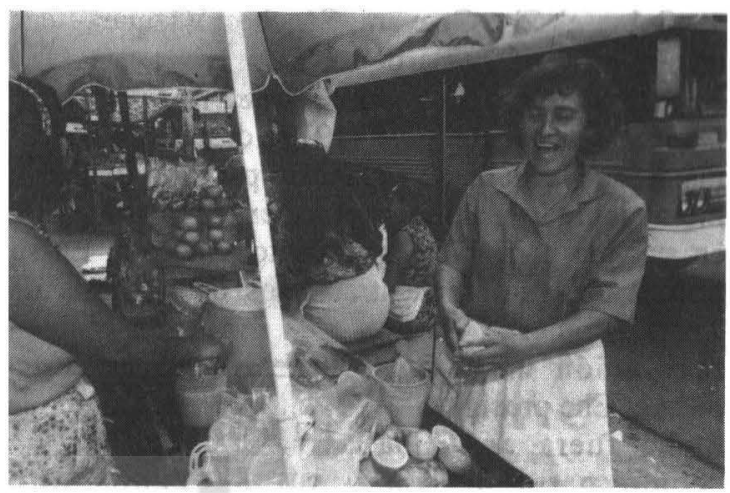

Los dos primeros acontecimientos lo llevan a acercarse al marxismo humanista que, con autores como Karel Kosik, Adam Schaff, Gajo Petrovic, Mihailo Markovic y otros, pugna por hacerse un lugar en el debate marxista. El tercer acontecimiento lo lleva a reivindicar la necesidad de superar las prácticas burocráticas de los partidos comunistas, uniendo pensamiento y acción, tal como lo hizo el Che Guevara.

Sánchez Vázquez, por opción y por vocación, es un marxista latinoamericano. Su marxismo se desarrolla, esencialmente, en la Facultad de Filosofía y Letras de la Universidad Nacional Autónoma de México (UNAM), desde donde establece relaciones con el marxismo humanista europeo. Al igual que el que cultivan los europeos, el de Sánchez Vázquez es un marxismo crítico y abierto. En su libro fundamental, Filosofia de la praxis (1967), defiende, siguiendo a Gramsci, que la reflexión sobre la praxis es lo que caracteriza al marxismo. Llega incluso a definir la praxis como la unidad de conocimiento, crítica de lo existente y proyecto de transformación. Según él, esos son los elementos esenciales del pensamiento de Marx, mismos que pueden ser rastreados a lo largo de su obra que es una sola desde los Manuscritos de 1844 hasta El Capital. El estalinismo (el marxismoleninismo) no toma en cuenta las tres dimensiones de la prexis señaladas, con lo cual termina por convertirse en una cortina ideológica tendida para legitimar el poder de una burocracia partidaria sobre el conjunto de la sociedad.

23. Cosa que hasta el día de hoy no se cansan de repetir los comunistas cubanos. Ver, por ejemplo, la ponencia de la delegación cubana en el VI Encuentro del Foro de Sao Paulo. L. A. González, "Izquierda, democracia y neoliberalismo: reflexiones sobre el VI Encuentro del Foro de Sao Paulo". ECA, No 573-574, julio-agosto de 1996, pp. 638-643. 
Sobre el Che Guevara, Sánchez Vázquez tiene una opinión bien particular. En sus escritos $E l$ socialismo y el Che (1967) y Diez años después: la gran lección del Che (1977) destaca el humanismo de Guevara, su capacidad para privilegiar lo moral sobre lo material y el haber logrado vincular en su vida personal pensamiento y acción. En su primer texto se encuentran ecos de las tesis de Trotsky acerca de la revolución universal, pues el Che prosiguió su lucha fuera de Cuba "como parte de una lucha total que sólo podría terminar con la disolución del imperialismo y la instauración a escala mundial del socialismo". En el segundo texto critica a los que consideran la lucha del Che como una aventura. A estos los llama "cautelosos estrategas burocratizados". Destaca que Guevara es un modelo para la creación del hombre nuevo, pues con él ese ideal se hizo viable.

Haciendo un recorrido sobre el significado de su obra filosófica, Sánchez Vázquez reitera su confianza en el maxismo. "Sigo convencido - dice en el artículo Postescriptum político filosofico a mi obra filosofica (1985) - de que el marxismo sigue siendo la teoría más fecunda para quienes están convencidos de la necesidad de transformar el mundo en el que no sólo se genera hoy como ayer la explotación de los hombres y los pueblos, sino también un riesgo mortal para la supervivencia de la humanidad".

Con el esfuerzo intelectual de Adolfo Sánchez
Vázquez se cierra, para el socialismo-comunismo latinoamericamo, el siglo $\mathrm{XX}^{24}$. ¿Qué más puede decirse filosóficamente sobre el marxismo latinoamericano -desde el interior del marxismo y respetando los supuestos que le son propiosmás allá de lo dicho y escrito por Sánchez Vázquez? ¿Acaso con él finalizan los intentos de sistematizar rigorosamente los diversos ámbitos de la realidad social, política y económica desde esta filosofía de la praxis? Si alguien más quiere hacer el intento, ¿qué novedad podría aportar? Estas son las preguntas pendientes para el socialismo-comunismo latinoamericano en un momento en el cual los éxitos han terminado siendo opacados por los fracasos.
5. Comunismo: pasión revolucionaria y compromiso militante

Hasta ahora se ha analizado la dimensión "conceptual" de las ideologías políticas, en particular del socialismo-comunismo. Pero estas ideologías tienen una dimensión pasional sin la cual, sobre todo en el caso de esta última, hubiese sido imposible el sacrificio y la entrega sin límites de sus militantes. El caso de Tina Modotti ilustra paradigmáticamente esta dimensión pasional. Antes de entrar al examen de la vida de esta militante es pertinente señalar que la pasión comunista se desató con gran intensidad en Europa -entre sus principales figuras intelectuales- después del triunfo bolchevique de octubre de 1917 y durante la época de la lucha antifascista ${ }^{25}$.

24. En el terreno de las ciencias sociales, las elaboraciones más importantes, influidas por el marxismo, se agruparon en las escuelas de la dependencia - las tendencias representadas por Gunder Frank, Cardoso y Falleto, y Mauro Marini- cuyo influjo se vino abajo con la llegada de los regimenes militares de los años sesenta y setenta. Ya fuese que se inspiraran en las tesis económicas de Marx o en los planteamientos de la CEPAL, la apuesta política de los dependentistas era por la revolución cubana, en el marco de la cual sus aportes cobran significado. Ver A. Gunder Frank, América Latina. Subdesarrollo y revolución, México, 1969; R. M. Marini, Subdesarrollo y revolución, México, 1969; F. H. Cardoso, E. Falleto, Dependencia y desarrollo en América Latina, México, 1969; O. Caputo, R. Pizarro, Dependencia y relaciones internacionales, San José (Costa Rica), 1974; Varios autores, América Latina: dependencia y subdesarrollo, San José (Costa Rica), 1975.

25. Sobre este tema, ver el interesante desarrollo que hace F. Furet en su libro El pasado de una ilusión. Ensayo sobre la idea comunista en el siglo XX, México, 1995. 


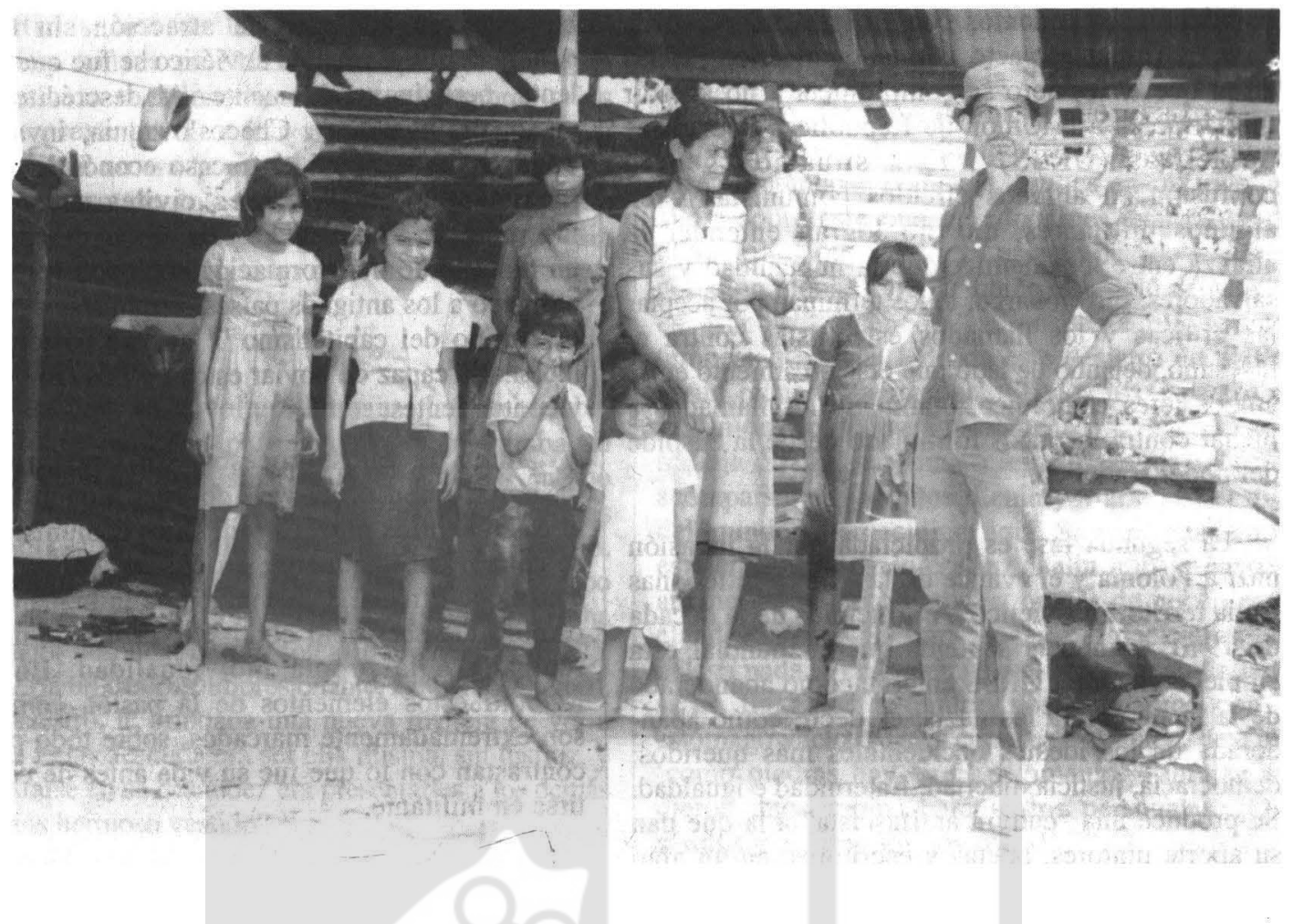

En efecto, para muchos intelectuales europeos ${ }^{26}$ la revolución bolchevique puso de manifiesto que la salvación de la humanidad era posible históricamente; es decir, 1917 demostraba que la Ilustración no sólo era una emancipación racional, sino una emancipación material. Ciertamente, se trata del primer experimento político que tiene como meta la justicia y la igualdad socioeconómica de las grandes masas de la sociedad. Por ello es vista por sus defensores como una continuación de la revolución francesa, en línea directa con las mejores tradiciones revolucionarias occidentales. La voluntad humana, con la revolución rusa, se sobrepone sobre cualquier obstáculo para la emancipación total.

Asimismo, la amenaza contrarrevolucionaria de los primeros años de poder soviético es vista como la reacción propia del antiguo régimen que busca conservar sus privilegios, oponiéndose al progreso. El terror rojo, al igual que el de Robespierre, es una necesidad ineludible de la revolución: Lenin es el Robespierre ruso, quien por lo demás continúa el esfuerzo de reforma social iniciado por Rousseau. Este es el marco que sirve de justificación a las purgas estalinianas de los años treinta-treinta y cinco, una vez que Stalin se ha consolidado en el poder tras la muerte de Lenin (1924).

A finales de los años treinta, cuando el poder de atracción de octubre comienza a perderse, Stalin abandera la lucha antifascista con lo que el espíritu libertador de los comunistas rusos es recuperado con inusitada fuerza. Con todo, no hay que perder de vista que el antifascismo estalinista tiene dos fases bien distintas entre sí: en la primera, que abarca prácticamente los años treinta, Stalin promueve la crítica al fascismo, pero de hecho

26. No es ninguna exageración que el comunismo apasionó, sobre todo en su época heroica, a los intelectuales europeos más importantes. Pero, también muchos fueron víctimas de la caza de brujas estalinista o de las pretensiones de la burocracia comunista por controlar el pensamiento independiente y despertar las pasiones más irracionales. Sobre este último punto, el libro de G. Orwel 1984 (Barcelona, 1952) es ilustrativo. Un recuento de los intelectuales víctimas de la persecución comunista entre 1920 y 1960 se encuentra en el libro de J. Rulhe Literatura y revolución, Barcelona, 1963. 
mantiene acercamientos con Hitler a tal punto de llegar a firmar el pacto germano-soviético (1939) en el que el primero se comprometa a no agredir militarmente a la Unión de Repúblicas Socialistas Soviéticas (URSS) ${ }^{27}$. Esta situación genera confusión en algunos círculos comunistas y en algunos militantes, que no logran entender la alianza entre los enemigos de la humanidad y sus salvadores. Sin embargo, todos terminan por aceptar las críticas y los llamados estalinistas contra el fascismo, dejando de lado que el acercamiento entre ambos jefes contradice totalmente los llamados a luchar contra los nazis formulado desde la cúspide del poder soviético.

La segunda fase es propiciada por la invasión nazi a Polonia y el avance de las tropas hitlerianas hacia territorio soviético. A principios de la década de 1940, cuando la segunda guerra mundial está en pleno vapor, la URSS emerge como abanderada de la lucha contra los nazis; es decir, como abanderada de los ideales occidentales más queridos: democracia, justicia, libertad, fratemidad e igualdad. Se produce una "cultura antifascista" a la que dan su aporte pintores, poetas y escritores, en un afán de sumar esfuerzos en pro de la libertad. Los sufrimientos del pueblo ruso y, más aún, la obra "liberadora" del ejército soviético en Europa del Este $^{28}$, erigen al modelo soviético como la mejor realización de los ideales humanos más profundos.

La muerte de Stalin, en 1953, y el XX Congreso del Partido Comunista de la Unión Soviética ${ }^{29}$, en 1956, permiten sacar a la luz pública lo que la fuerza pasional del comunismo no permitía ver: los crímenes de Stalin, los campos de concentración soviéticos y el engaño sistemático promovido por el jefe comunista muerto tres años atrás. De ese entonces en adelante, la atracción sin límites generada por el modelo soviético se fue quebrando lenta, pero inexorablemente. Al descrédito internacional (invasión a Checoslovaquia, invasión a Afganistán) se sumó el fracaso económico ${ }^{30}$; a la inexistencia de libertades civiles se sumó la incompetencia política. La perestroika desencadenó un proceso de transformación sociopolítica que ha obligado a los antiguos países comunistas a reandar el camino del capitalismo ${ }^{31}$. No hay pasión revolucionaria capaz de obviar estos hechos tan brutales y contundentes.

Antes de estos procesos, sin embargo, esta pasión se impuso. La vida de Tina Modotti ilustra el caso de otros muchos militantes comunistas que se entregaron totalmente, en cuerpo y alma, a una causa que ofrecía la redención de la humanidad a cambio del sacrificio cotidiano, la disciplina y la renuncia a la propia individualidad. En Tina Modotti estos elementos de la pasión comunista son extremadamente marcados, sobre todo porque contrastan con lo que fue su vida antes de convertirse en militante.

El libro Tinisima ${ }^{32}$, de Elena Poniatowska, es un homenaje a esa mujer -fotógrafa de profesión- que ejerció su poder de seducción sobre la intelectualidad mexicana de los años veinte. Antes de su compromiso revolucionario, frecuentó los círculos formados por pintores, poetas y fotógrafos en los cuales se abría espacio por su belleza y sensualidad. No sólo los demás le rendían culto a su cuerpo, sino que ella misma estaba absorbida por las experiencias afectivas que era capaz de suscitar. En esta etapa de su vida era una mujer que vivía para el placer y los sentidos, sin ocultarse ni ocultarlo. Por tratarse de una época donde la

27. Furet, en el libro citado, documenta exhaustivamente las afinidades existentes entre el régimen estalinista y el régimen nazi, afirmando que ambos comparten la misma naturaleza totalitaria. E. Nolte, por su parte, insiste en la magnitud del exterminio social practicado por los bolcheviques, el cual tuvo su contrapartida en el exterminio étnico y biológico practicado por los nazis. Ver E. Nolte, Después del comunismo. Aportaciones a la interpretación de la historia del siglo XX, Barcelona, 1995.

28. En donde, dicho sea de paso, se instauran por la fuerza regímenes políticos calcados del modelo soviético: partido único, ausencia de libertades civiles, economía planificada centralmente y desmembramiento de las sociedades civiles que en algunos países, antes de la "liberación soviética", tenían un desarrollo notable.

29. Ver I. Deutscher, Rusia, China y Occidente, México, 1974.

30. Ver F. J. Ibisate, Las economias del Este y sus perspectivas, San Salvador, 1996.

31. Para tener una idea de cómo fue percibido este desafío antes del derrumbre de la Unión de Repúblicas Socialistas Soviéticas por intelectuales soviéticos y no soviéticos. Ver F. Claudín, La perestroika. ¿A dónde va la Unión Soviética?, Madrid, 1990.

32. E. Poniatowska, Tinísima, México, 1993. 
libertad sexual de las mujeres no podía ser ni siquiera soñada en México, Modotti fue sin duda alguna una cuestionadora de las costumbres y los tabúes sexuales. Fue una mujer que vivió en una época que no era la suya —l México provinciano y ranchero de los años veinte- y en la que reivindicó su derecho a gozar sensiblemente sin estar atada a $\longrightarrow$ o depender de - un hombre.

\section{Agosto de 1923.}

"La piel, su envoltura humana, la completaba. No tenía palabras para decirlo, reinventaba su relación consigo misma, se quería. Si su cuerpo podía transmitir esa fuerza, la profundidad de las sombras, la armonía y el ritmo de su diseño, entonces ella también sería inolvidable. Su cuerpo allí en el papel [en la fotografía que Weston le ha tomado, desnuda, en la azotea] trabajaba sobre ella, adquiria un carácter impresionante. Edward [Weston], su maestro, le brindaba una nueva manera de ver a Tina. Estar desnuda era ser ella misma, sin disfraz, y mostrarse en su desnudez era presentarles a los demás su más hermoso vestido" ${ }^{33}$.

Su presencia en los círculos intelectuales le permiten entablar relaciones con Julio Antonio Mella, a quien no tarda en seducir con su belleza y con quien vive un intenso romance que dura hasta el asesinato de éste, en enero de 1929, cuando caminaban del brazo por una de las calles de la ciudad de México. La experiencia amorosa con Mella y la difícil situación que le acarrea su muerte - las autoridades mexicanas la acusan de cómplice en el asesinato del comunista cubano- la vinculan a los círculos comunistas de este país en actividades de propaganda y denuncia. Bajo la sospecha de haber participado en un atentado contra el presidente de México es encarcelada; en consecuencia, la amenaza de deportarla a su país, una Italia dominada por Mussolini, no se hace esperar. Una vez deportada, en 1930 , recibe la ayuda del militante comunista Vittorio Vidali (Enea Sormenti) quien prepara las condiciones para que ella pueda viajar a Alemania (con Hitler amenazante) donde los comunistas le ayudan a viajar a la Unión Soviética.

\section{Octubre de 1930.}

"Tina desemboca en la Plaza Roja, del brazo de Vittorio. De tan extenso, el adoquinado parece ondular. 'Nunca he visto una plaza así de enorme', dice apretándose contra él, 'nunca en mi vida'. Y ahora sobre este mar de adoquines avanzan hacia el Kremlin amurallado, su palacio pesado y secreto como un monseario. 'También el zócalo de México es grande, dicen que ahí cabe la más grande tempestad'. 'Si al lado de este desiento de piedra, es un recuerdo acogedor'. 'Todos los espacios de la Unión Soviética son inmensos'... 'Mira, aquí trabaja Stalin, en una oficina desnuda, sólo lo acompañan dos retratos: Lenin y Marx... El destino del mundo va a decidirse aquí. Su ventana siempre está encendida, bajo esa luz Stalin trabaja hasta el amanecer. Se acostumbró a bregar de noche en la clandestinidad. El toma todas las decisiones, no delega nada. Ven, tenemos que cenar en algún lado, si no llegamos a tiempo nos quedamos con el estómago vacío. ¿Traes cupones?' 'Tantos, ríe Tina, 'como piedras hay en el pavimento. También me dieron unos rublos para gastos personales. ;Qué cálidos y atentos son los rusos!' "rast.

Prácticamente, aquí se inicia la radical conversión de Tina Modotti. En efecto, es reclutada por la Intemacional Comunista como una agente en el exterior, previo entrenamiento y comprobación de su fidelidad al comunismo. Tras varias misiones a Alemania en su calidad de agente secreto, a mediados de los años treinta la envian a su prueba más difícil: la guerra civil española. Pelea contra las tropas franquistas, moviliza y cura heridos, pero fundamentalmente sigue las órdenes del camarada Stalin. Su vida personal se sacrifica en la lucha de los comunistas por la República, con disciplina y fervor, pero en el fondo su vida está consagrada a Stalin. La perturban los acercamientos de éste con Hitler, pero está segura de que la fidelidad del jefe comunista al pueblo soviético y a los pueblos del mundo no puede ser puesta en duda.

Enero de 1935.

"Camarada Modotti [le dice su responsable

33. Ibid., pp. 140-141.

34. Ibid., p. 329. 
Stásova], deberá ir a España. Usted va a luchar al lado de los camaradas asturianos... - $i$ Cuándo debo salir? -Mañana, esta misión será más larga que otras; tendrá que llevar sus efectos personales; la situación en España es incierta"3s.

\section{Noviembre de 1936.}

"Hace dos días comenzaron los bombardeos sistemáticos a Madrid. Madrid arde destechada. Los aviones nacionalistas vuelan bajo y ven a los madrileños correr por la calle... Cuando puede dejar de guardia a Sebastián, Tina sube a ayudar a las salas. Los heridos la llaman porque sabe escucharlos... Tina nota que se le hinchan las piernas, pero le molestan menos que el vapor de los peroles" ${ }^{36}$.

\section{Julio de 1937.}

"Hace mucho que Tina rebasó su nivel de agotamiento y en sus ojos se lee una fiereza que antes no tenían. No así su cuerpo adelgazado y quebradizo. Gerda Taro, su Rolleiflex hombro, la irrita y la atrae. Bonita, los hombres la enamoran. Lo mismo a la Valero. "¿Habré olvidado que soy mujer?’, se pregunta Tina”37

\section{Enero de 1939.}

"Franco entra en Barcelona. El éxodo de quinientos mil refugiados desde Cataluña es alucinante; frío, lluvia, nieve, falta de provisiones, bombardeos despiadados. Miles de civiles rumbo a la frontera avanzan a tropezones, defendidos por divisiones del ejército de la República a costa de sacrificios enormes"38

La derrota de la República le duele, y como otros tantos vencidos tiene que abandonar España y embarcarse hacia otro país. Vuelve a México donde es recibida por antiguos amigos que le manifiestan cariño, aunque ya no la efusividad de antes. Tina Modotti es otra; incluso muchos no logran reconocerla. Está vieja y cansada. La militancia comunista la hizo olvidarse totalmente de sí misma, al punto de haber perdido la costumbre de verse en un espejo, pues esa era una costumbre burguesa que desviaba la atención de las necesidades de la lucha revolucionaria. Muere olvidada de sí misma y olvidada por los demás -en el asiento trasero de un taxi en marcha - mientras se dirige a su casa.

\section{Abril de 1939.}

"El barco de Tina llegará a Veracruz el 19 de abril, es una carrera contra el tiempo: si no lo ve [a Vittorio] en el muelle mexicano va a sentirse mal. Hay que avisar a los del partido en México, a Rafael Carrillo, a Hemán Laborde, a quien encuentre, para que compañeros de confianza lleguen a recibirla. Al describirla siente que se le cierra la garganta. -Es seguro que lleve una chaqueta negra y un sombrero negro, muy modestos ambos, la vista siempre baja, casi sin equipaje, de estatura más bien pequeña. Nadie debe enterarse de que María o Carmen Ruiz Sánchez, de nacionalidad española, doctora, profesora o lo que sea, es la presunta autora del frustrado asesinato, hace nueve años, del entonces presidente de México, Pascual Ortiz Rubio.

Nadie se dio cuenta de que la española Carmen Ruiz Sánchez, de ojos muy hundidos, tez ajada y manos temblorosas, era la Tina Modotti expulsada en enero de 1930. Al contrario, cuando un inspector la vio tambalearse, le gritó a un secretario: ayúdala, hombre, ¿que no ves que es una persona de edad?"39.

\section{Enero de 1942.}

Vittorio la espera leyendo. Cuando suena el timbre se da cuenta de que es más de la una y baja la escalera. A Tina se le habrán olvidado las llaves. Dos señores le dan las buenas noches y preguntan por el marido de la señora Tina Modotti. - Yo soy, ¿dónde está la señora? - ¿Quiere usted que nosotros nos ocupemos? - ¿Le pasó algo?Falleció. - Un momento, ¿de qué me están hablando? - Su esposa, Tina Modotti, murio en un libre en la acera de aquí enfrente. El taxista la llevó a la Cruz Roja. Nosotros trabajamos en pompas

35. Ibid. p. 408.

36. lbld., pp. 463-474.

37. lbed., p. 530.

38. Ibid., p. 559-560.

39. Ibid., p. 580. 
fúnebres y estamos a sus órdenes...

"Cuando el libre se detuvo, en la esquina de Insurgentes y la calle de Villalongín, Tina dio su dirección de doctor Balmis y el chofer preguntó: - ¿dónde mero? -Frente al Hospital General.

-Bueno, la llevo... El taxi se detuvo frente al Hospital General.

-Servida, señora. El chofer oyó que la mujer se quejaba quedito, abrió la puerta trasera del coche $y$ la rozó. - Señora, ya llegamos. Al verla inmovil, entró corriendo a la guardia del hospital y señaló su taxi. Después de insistir, lo siguieron dos practicantes. -Se hizo tarde, mano, ya se murió, llévala a la Verde. Allí la entregas"40.

Tina Modotti, una mujer bella y sensual, que vivía para sí misma, queriendo hacer de su individualidad el centro del mundo. Tina Modotti, cansada y con ojeras, sin lavarse los dientes y verse al espejo, entregada totalmente a una causa que traería la salvación definitiva a los pobres de la tierra. Suman miles las personas, hombres y mujeres, que tuvieron una conversión similar. Suman miles las personas, hombres y mujeres, que alimentaron con su sacrificio personal y su disciplina la ideología comunista. Esta fue la clave de su fuerza, pero también del fanatismo y el dogmatismo que la caracterizaron a lo largo del siglo $\mathrm{XX}$.

\section{Reflexión final: la incertidumbre de fin de siglo}

A estas alturas, los grandes proyectos ideológicos -nacionalismo, antiimperialismo, nacionalismo revolucionario, socialismo-comunismoparecen haberse quebrado. A nivel práctico político fueron proyectos que se hicieron o estuvieron a punto de hacerse del poder. A nivel teórico, como sistemas explicativos de la realidad social, económica y política, tuvieron un fuerte impacto no sólo entre grupos intelectuales, sino entre amplias capas populares. A nivel pasional, fueron esquemas motivadores de la acción política directa y el compromiso militante.
Esas ideologías políticas lograron reunir de un modo u otro esos tres aspectos. De allí su éxito movilizador y su impacto en el debate intelectual. Indudablemente, la que mejor lo hizo fue la ideología socialista-comunista: la pretensión científica de sus planteamientos teóricos se vio avalada por la eficacia política de las ideas defendidas - la máxima prueba de ello era la Unión de Repúblicas Socialistas Soviéticas-; y ambos aspectos -el conocimiento y la eficacia- fueron combinados por una pasión sin límite de sus militantes, quienes siempre estuvieron seguros de la justicia de su causa, de la legitimidad de los métodos aplicados para lograr sus objetivos y del triunfo definitivo.

Nacionalismo, antiimperialismo, nacionalismo revolucionario se fueron quebrando paulatinamente. Hacia los años sesenta sólo quedaban ecos de los mismos en los planteamientos de la modernización y la CEPAL ${ }^{41}$. Sólo se trataba de ecos: aunque el desarrollo nacional continuaba en la mesa de discusión, el compromiso militante había sido reemplazado por el compromiso burocrático de los especialistas (economistas, sociólogos y políticos de profesión). El golpe mortal vino con las dictaduras militares de los años sesenta y setenta. Entre tanto, la ideología comunista no sólo resistió, como ideología, la embestida de los militares, sino que se robusteció con la represión. Los militares parecieron darle la razón: la violencia era la única vía para construir una nueva sociedad.

El socialismo-comunismo comienza su recorrido por la realidad latinoamericana desde los años veinte y treinta. Desde aquellos años comienza a revelar su fuerza y su "superioridad" respecto de las demás ideologías políticas: coherencia y simpleza teóricas $^{42}$ (todo tiente una respuesta lógica), y pasión militante, junto a la prueba soviética de que el proyecto era políticamente viable. Incluso, el socialismo-comunismo latinoamericano contribuyó al fracaso de las otras propuestas ideológicas, que fueron atacadas frontalmente por no ser la "verdadera" expresión del compromiso revolucionario. Nadie podía ocupar el lugar de los socialistas-comunistas

40. Ibid. pp. 653-654.

41. Ver R. Prebish, "El desarrollo de América Latina y algunos de sus principales problemas". En A. Gurrieri, La obra de Prebish en la CEPAL, México, 1982; G. O'Donnel, Modernización y autoritarismo, Barcelona, 1972.

42. La mejor expresión de ello se encuentra en la obra de Marta Hameker, especialmente en su célebre manual de 
en su papel de "verdaderos" revolucionarios.

La revolución cubana afianzó las certezas del socialismo-comunismo latinoamericano. Nicaragua y El Salvador también. Pero esto hasta los años ochenta. La quiebra del modelo soviético no vino sola. Con ella vino la crítica a las inconsistencias teóricas de los diversos marxismos, especialmente de ese esperpento llamado marxismo-leninismo. Emergió también una revalorización de los individuos, con sus sueños y esperanzas. $Y$ por supuesto vino la embestida neoliberal, como elemento acompañante de la reestructuración del capitalismo a nivel mundial ${ }^{43}$. En este escenario, la última de las grandes certezas ideológicas que quedaba en pie terminó por revelar sus inconsistencias más profundas. Esta es, pues, una época de gran incertidumbre ideológica y política para los latinoamericanos. Lo único que queda es la apuesta por la democracia con la que esperamos el advenimiento del nuevo siglo ${ }^{44}$.

marxismo-leninismo -influido por su aprendizaje con Louis Althusser- que fue lectura obligatoria para cientos de militantes comunistas. Harneker es, sin duda alguna, la gran vulgarizadora del marxismo-leninismo en América Latina, pero más allá de eso no tiene mayores méritos para figurar en la historia de las ideologías políticas.

43. Ver L. Thurow, La guerra del siglo XXI, Buenos Aires, 1992.

44. Ver Baba Solano, C. y cols. Transiciones a la democracia en Europa y América Latina, México, 1991; G. O'Donnel, Ph. C. Schmitter y L. Whithead (Comps.), Transiciones desde un gobierno autoritario, Buenos Aires, 1988. 